No. 11,1977

\title{
A COMPARATIVE STUDY OF COMPLETE SYSTEMS OF DEMAND FUNCTIONS \\ by
}

N. Anders K1evmarken

March, 1977

This is a preliminary paper. It is intended for private circulation, and should not be quoted or referred to in publications without permission of the author. Comments are welcome. 


\title{
A COMPARATIVE STUDY OF COMPLETE SYSTEMS OF DEMAND FUNCTIONS
}

\author{
by
}

N. Anders KLemarken

Ten models of consumer demand, including the indirect translog model, the linear ecpenditure system and the Rotterdam model, are applied to Swedish data and compared, using fit and predictive performance as criteria. Data include 8 food comodities. Demand models tend to be superior to naive models, but nonadditive models are not clearly better than additive. Each model is estimated on two levels of commodity aggregation. The results show that the estimated structures depend on the level of aggrem gation.

\section{Introduction}

Complete systems of denand functions have becone a comoniy applied tool for economic policy and forecasting. Nevertheless, the application of these models is burdened by both theoretical and practical problems. It is well known that some implications of the theory of denand, like homogeneity and symmetry, do not in general hold good on an aggregate level, and in studies by Barten [1969] and Christensen, Jorgenson and Lau [1975] the classical theory of demand is rejected. In other studies specific assumptions about the utility function, i.e. additivity, have been tested without relinquisining the tenets of classical demand theory. In, for instance, Deaton $[1974$ a] the hypotheses of an additive utility function was rejected.

However, in practice data relative to the desired detailed commodity breakdown are scarce and price variation is usually in-

This research was carried out with financial support from the Swedish Council for Social Science Research and the Industrial Institute for Economic and Social Research (IUI). The author has had the benefit of comments from Claes Dolk and Ed PaImer. 
sufictent to give we1l detemined estimated denand responses to price changes. In order to estinate our nodels we thus need a pxtan restrictions to reduce the number of unknown parameters, aut the only basis we have for choosing such restrictions is the theory of demand. In spite of the impliçations of previous results, since data are scarce, our problem is to detemine whether the classical theory of demand with and without its more restrictive assumptions, like aditivity, is good enough to be used in forecasting.

To compensate for a low infomational content in data, long time series are needed to obtain sharp tests. In the studies by Barten [1969] and by Christensen, Jorgenson and Lau [1975] the samble period included 31 and 44 years respectively. Deaton's [1974 a] study was also based on long time series covering the period 1900-1970, which, with the war years excluded, gave 48 years. This is more than one can usually expect to find but what is more important, one may question the validity of these long time series. Comodities included in today's aggregates are vastiy different from those included at the beginning of the century. Everyone experienced in the complation of expenditure and price series is aware of the great difficulties, not only in obtaining consistent series, but also in obtaining reliable series. The consequent "ad hoccery" involved in this kind of statistical work is annoying. Wh these difficulties to contend with, it is perhaps not so surm prising that some of the classical results of demand theory fail to gain statistical support, whereas on the other hand it suggests that the empirical results might be more favourable were higher quality data available.

There are a number of comparative studies, most of which are based on fit criteria (i.e. Parks [1969], Yoshihara [1969], Coldberger and Gamaletsos [1970], Dahlman and Klevmarken [1971], Gamaletsos [1973], Deaton [1974 a] and Theil [1975]). Is is difficult adequately to sumarize the results from these studies. Differences in details of model specification, in estimation methods, in definitions of connodities and in compilation of data may at least partIy explain the sometimes conflicting results. However, in most studies, nodels which donotimply an additive witilty function show a closer fit to data than those which do. Thus, in a number of studies, variants of the Rotterdan system show themselves superior to, 
for instance, the Iinear expenditure system and the direct and indirect addilog models (Parks [1969], Deaton [1974 an and Theil [1975]). The reported differences in fit between addituve models like the Inear expenditure system, the addilog models and the Rotterdan system with additivity enforced are smaller and inconsistent. One may also note that the constant elasticity demand system or the double logarithic model usually obtains a relatively high ranking by fit.

There are only a few studies of relative predictive performance. One example is that of Theil [1975]. His results on British data with four commodities show that his Rotterdam system with block independence has a better performance than the indirect addilog model and the Iinear expenditure system. The information inaccuracy measure for the Iinear expenditure system is even higher than for one of Theil's naive models.

It is a general finding that the estimated elasticities are very sensitive to the model specification. Large differences are found between different models estimated on the same data.

In the present study ten models, including two naive models, are applied to Swedish data and compared, using fit, predictive perfomance and sign and magnitude of estimated elasticities as criteria. In principle, predictions and estimated elasticities depend in a more than trivial sense on the commodity aggregation. In order to explore the aggregation effects each model is estinated twice, once for a forr comodity break-down and once for an eight commodity breakwom.

Our data include only food commodities. There are several reasons for limiting the study to food. First, the data for food are of a mch higher quality than data for other comodity groups. Second, food is non-durable and third, the food market functions relatively freely without the institutional restrictions that limit trade in, for instance, the housing market. Behind this confinement of the study to the demand for food there is an implicit assumption of a weakly separable utility function. 


\section{Alternative models}

There are two naive models to serve as a reference base in evaluating the explanatory ability and predictive perfomance of the other eight models. They can never, of course, be a substitute for a demand model in simulations of the effects of economic policy. The particular choice of a naive model is somewhat arbitrary. Loosely speaking, expenditure shares are more stable than expenditures, volumes and rates of change in volume. A naive model may thus be more successful in explaining and forecasting expenditure shares than any of the other variables. The first model is thus a trend in expenditure shares and the second a simple autoregressive structure, also in expenditure shares.

Except for the last model below, the remaining seven models have been chosen because they belong to those most commonly applied. Although the constant elasticity of demand model does not satisfy the properties of classical denand theory it has been, since Schultz [1938] and Wold [1952], the best known and most used model of them al1, one of its merits being the ease of estimation. To emphasize simplicity, one of the two versions estimated, has no cross-price elasticities. The second version includes all price effects. The possibility of gaining degrees of freedom by local enforcenent of the constraints of classical demand theory (cf.Byron [1970]) has not been used. A more recent development with approximately the same advantages and disadvantages is the Rotterdam system (Theil [1965]). Both these models may be looked upon as approximations to an underlying classical denand model. Of the models which do satisfy the constraints of classical demand theory Stone's linear expenditure system (Stone [1954]) is the most widely used (cf. Brown and Deaton [1972]). It is easy to interpret, and although it involves non-Iinear estimation it is not too difficult to estimate. It has also proved to be a good starting point for useful generalizations, one of which is included in this study, namely the linear expenditure system with habit formation (cf. Pollak and Wales [1969], Pollak [1970] and Dahlman and Klevmarken [1971]). Possible rivals to the linear expenditure system are the addilog models Houthakker [1960]). There is, however, no conclusive evidence which puts the 
addilog models before the Iinear expenditure system and they are, in addition, more difficult to estimate. They have therefore not been used in this study. A possible disadvantage of both the linear expenditure system and the addilog models is that they are derived from an additive utility function. This implies that there are no specific substitution effects and that the own-price elasticity is approximately proportional to the income elasticity, as shown in Deaton [1974 b]. In recent years more general models have been developed, one of which is the translog model Christensen, Jorgenson and Lav [1975], Christensen and Manser [1977]). The version used here is derived from an indirect utility function, the logaritm of which is of second degree in the logarithin of the price-income ratios. The increased generality, however, is bought at the price of a more difficult estimation and there are as yet but few applications of these models. 1)

In the comparative studies by Brown and Deaton [1972], Deaton [1974 a] and Theil [1975], the authors argue that the lefthand variables of the competing models should be comparable. They should, for instance, all be expenditure shares or log-changes in expenditure shares. If not, the measures of fit may by definition favour one model before another. In our study, this recommendation is not entirely followed. Each model is prefered in its most commonly applied fom, which implies that the stochastic structure will vary from one model to another. However, some of the models which are not usually formulated as expenditure share equations have also been estimated in this form. ${ }^{2}$.

1) This is not the place to analyse in detail the theoretical properties of the models used. The reader is directed to the references given and to the excellent review article by Brown and Deaton [1972].

2) This transfomation is also motivated by heteroscedasticity in consumption expenditures and volumes. In Theil [1975], chap. 5, it is also argued that autocorrelation could be removed by taking first differences. 
The following notation is used for all models:

$q_{i t}$ demanded volume per head of commodity in year $t$,

$p_{i t}$ price of commodity i in year $t$,

$w_{\text {it }}$ expenditure share of commodity $i$ in year $t$.

$w_{i t}^{*} \frac{1}{2}\left(w_{i t}+w_{1 t}-1\right)^{*}$

$y_{t}$ total food consumption per head in current prices in year $t$,

$p_{t} \quad$ price index for food in year $t$,

$\varepsilon_{\text {it }}$ stochastic disturbance for commodity $i$ in year $t$,

$e_{i}$ income elasticity for commodity i.

$E_{i j}$ (uncompensated) price-elasticity,

n number of commodities

$\alpha, \beta, c, \pi, k, \infty$ are parameters. They do not necessarily have the same interpretation in all models. In the Constant Elasticity of Demand Systems, eq. (3) and (4) below, $e_{i}$ and $E_{i j}$ are also parameters. The operator $D$ is the logarithmic difference operator. Results are reported for the following ten models:

Trend (Trend-w)
$w_{i t}=\alpha_{i}+\beta_{i} t+\varepsilon_{i} \varepsilon^{5}$
$i=1, \ldots, \mathrm{n}$

Autoregressive model. (Auto-w)

$w_{i t}=\alpha_{i}+\beta_{i} w_{1} t-1+\varepsilon_{i t} ;$

$i=1, \ldots, n$

Constant Elasticity of Demand System (CEDS-Inq)

$\ln \left(q_{i t}\right)=\alpha_{i}+e_{i} \ln \left(y_{t} / p_{t}\right)+E_{i i} \ln \left(p_{i t} / p_{t}\right)+\varepsilon_{i t} ; \quad i=1, \ldots, n$

Note that all crossmpice elasticities are assumed to equal zero. 
Constant Elasticity of Demand System (CEDS-Inw)

$$
\begin{aligned}
& \ln \left(w_{i t}\right)=\alpha_{i}+\left(e_{i}-1\right) \ln \left(y_{t} / p_{t}\right)+\left(E_{i i}+1\right) \ln \left(p_{i t} / p_{t}\right)+ \\
& \sum_{j} E_{i j} \ln \left(p_{j t} / p_{t}\right)+\varepsilon_{i t} \\
& i=1, \ldots n
\end{aligned}
$$

Symetry of price responses is not enforced. There are thus $\mathrm{n}(\mathrm{n}+2)$ parameters to estimate.

Linear Expenditure System with Habit formation (UESH-pq)

$$
\begin{aligned}
& p_{i t} q_{i t}=\alpha_{i} p_{i t} q_{i, t-1}+\beta_{i}\left(y_{t}-\sum_{k} \alpha_{k} p_{k t} q_{k, t-1}\right)+\varepsilon_{i t} i=1, \ldots, n \\
& \sum_{i} \beta_{i}=1
\end{aligned}
$$

Linear Expenditure System with Habit formation (LESH-W).

$$
\begin{aligned}
& w_{i t}=\alpha_{i} p_{i t} q_{i, t-1} / y_{t}+\beta_{i}\left(1-\sum_{k} \alpha_{k} p_{k t} q_{k} t-1 / y_{i}\right) \\
& +\varepsilon_{i t} ; \quad i=1, \ldots, \text { ins }_{0} \\
& \Sigma_{i} \beta_{i}=1: \\
& \text { Linear Expenditure System (LES-w). } \\
& w_{i t}=c_{i} p_{i t} / y_{t}+\beta_{i}\left(1-\sum c_{k} p_{k t} / y_{t}\right)+\varepsilon_{i t} \quad i=1, \ldots, n \\
& \Sigma B_{1}=1
\end{aligned}
$$

Rotterdan System $\left(\mathrm{RD}-\mathrm{w}^{*} \mathrm{DO}\right)$

$$
\begin{aligned}
& w_{i, t}^{*} D q_{i t}=\mu_{i} D q_{t}+\sum_{j} \pi_{i j} D p_{j t}+\varepsilon_{i t} \quad \dot{i}=1, \ldots, n \\
& \sum_{j} \pi_{j}=0 \text { for } a l 1 i \\
& \pi_{i j}=\pi_{j i} \text { for all } i \text { and } j \\
& \sum_{i}=1
\end{aligned}
$$


Rotterdan System with Intercept (RDI-W. Dq)

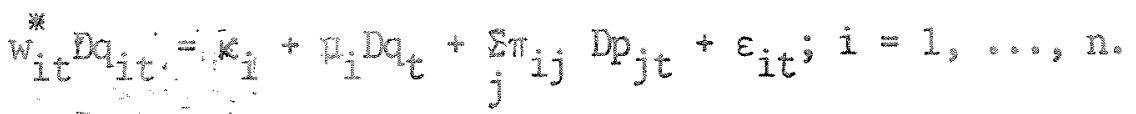

$\sum_{j} \pi_{i j}=0$ for all $i$

$\pi_{i j}=\pi_{j i}$ for all $i$ and $j$

$\sum_{i} \mu_{i}=1$

Indirect Trans log model (ITR-W).

$w_{i t}=\frac{\alpha_{i}+\sum_{j} \beta_{i j} \ln \left(p_{j t} / y_{t}\right)}{-1+\sum \beta_{M j} \ln \left(p_{j t} / y_{t}\right)}+\varepsilon_{i t} \quad \quad i=1, \ldots, n$

$B_{M j}=\sum_{i} \beta_{i j}$

$\beta_{i j}=\beta_{j i}$

The error terms may be contemperaneously correlated but no autocorrelation is assumed,

$$
\begin{aligned}
& E\left(\varepsilon_{i t}\right)=0 \\
& E\left(\varepsilon_{i s} \varepsilon_{j t}\right)= \begin{cases}\sigma_{i j} & \text { if } s=t \\
0 & \text { if } s t t\end{cases}
\end{aligned}
$$

Owing to the model specification and the enforcement of the budget constraint, the contemporaneous error moment matrix in models 5 to 10 is singular. In each of these models one equation is redundant and could be left out. With the estination methods used any equation could be dropped.

It was emphasized above that models (1)-(3) were included in this study because they are simple. This hoolds good a fortiori when it comes to estimation. Each equation has thus been estimated by OLS, although some gain in efficiency might have been obtained in models (2) and (3) by other methods. Model (4), the Constant Elasticity of Demand System with all price effects 
included, was efficiently estimated by OLS. The three versions of the Iinear expenditure system were estimated by the quasi- maximumlikelihood method, 3) and the two Rotterdam models were estimated by Zellner's iterative Aitken estimator (IZEF). The TSP program was used to estimate the translog model by a non-linear IZEF procedure. Owing to a restricted supply of computer programs and limited availability of programing faclities the same estimation procedure was not used for the last five models, but the maximum likelihood method and IZEF only differ computationally because, if convergent, IZEF will produce M estimates (Bradley [1973], Oberhofer and Knenta [1974], Charnes, Frome and Yu [1976], Christensen and Manser [1977]). No difficulty was experienced in obtaining convergence except with the translog model with elght comodities. This model has therefore been estinated with two altemative assumptions about the error moment matrix. First, the model was estimated as specified above with coarce tolerance limits. In a second estimation round with fine tolerance Iimits, the moment matrix was fixed at the values otbained at convergence in the first round. In this way convergence was obtained also with fine tolerance limits. The results are reported below under the heading ITRL-W, $\Omega$. The second version of the translog model was obtained by fixing the error monent matrix from the beginning in the following way,

$$
\begin{aligned}
& \sigma_{i j}=-\sigma^{2} w_{i j} \\
& \sigma_{i 1}=\sigma^{2}\left(1-w_{i}\right) w_{i}
\end{aligned}
$$

Where $\bar{W}_{i}$ is the average expenditure share for comodity $i$ and $\sigma^{2}$ is a constant. The heading used for results with this specification is $I T R L_{-}, \Omega_{0}$

3) The likelihood function for independently multivariate nomally distributed error terms was maximized by using the Harwell Library Sub-routine VAOSAD - a quasi-Newton procedure. 


\section{Data}

The series of expenditures and prices used are revisions of the series published in Dahiman \& Klevmarken [1971]. The sample period is 1950-1970. Wwo years, 1971 and 1972, are reserved for a comparison with ex post forecasts. Data were originally obtained for 16 food commodities, but for this study they were grouped into 8 commodities. Commodities exhibiting similar fluctuations in relative prices were grouped together. In order to study the effects of aggregation on estimated elasticities and predictions the 8 commodities were further aggregated into 4 comnodities. The fourcommodity breakdown is related to the eight-comodity breakdown as shown below.

\section{Commodities}

\section{Commodities}

1. Flour, Bread, Potatoes and derivat: ive products

2. Butter, Egg, Sugar, Spices

3. Milk, Cream

A. Basic Supplies

4. Vegetables

5. Fruit, Berries, Ice-cream, Chocolates B. Vegetables and Fruit and Sweets

6. Meat and Pork, Cheese

7. Fish

C. Meat and Fish

8. Restaurant Meals

D. Restaurant Meals

Note that the last commodity, "Restaurant Meals" is the same in the two groupings.

In principle each model will detemine the proper method of aggregation. Price indices will typically involve the unknown parameters. In this particular study it would be possible to use parameter estimates from the 8-commodity level and estimate price indices for the 4-comodity level. However, in practice this is usually not a feasible procedure, and we have opted in favour of the common practice of aggregating expenditures by simple sumation and using price indices of the Edgeworth and Laspeyres type. This makes our analysis of aggregation effects more realistic. 
4. Results

There is no obvious standard of comparison for our ten models. They are not nested, they do not have the same dependent variable and their stochastic properties differ. Owing to the fact that they are not nested there is no formal test for discriminating between them. A comparison of sample-period evidence has to be based on descriptive goodness of fit statistics. This comparison could be made for expenditure shares, expenditure levels, volumes or relative changes in volume. The results reported below are based exclusively on comparisons of expenditure shares. The statistics used are information inaccuracies and coefficients of determination. In addition to sample-period fit, the predictive performance for 1971 and 1972 is evaluated by using the same statistics. As a third criterion for discrimination between the ten models the estimated elasticities are evaluated against prior conceptions about their sign and size. For both levels of aggregation parallel results are presented, and this section concludes with some results of the aggregation effects.

Before turning to these results, however, we may report that our results for the translog model permit the same test of the theory of demand as in Christensen, Jorgenson \& Lau [1975]. Contrary to the conclusion reached in their study, we connot reject, on a 4 commodity level, the composite hypothesis that the $B_{M j}$ parameters in $(10 \mathrm{~b})$ take the same values in each equation and that symmetry according to $(10 \mathrm{c})$ is maintained $\left(\chi_{\mathrm{df}=6}=7.818\right.$ while the $5 \%$ critical value is 12.6$)^{4} \mathrm{j}$

\subsection{Goodness of fit . - - - - - -}

The first colum in Tables 1 and 2 give average information inaccuracies for each model for the whole sample period. The second column shows the same statistic, but corrected for degrees of freedom (see Theil [1971] p 649). The third column shows standard deviations for yearly information inaccuracies.

4) The sample period is too short to give the same test meaning on the eight commodity aggregation level. 
For the case of four commodities the linear expenditure system with habit formation yields the closest fit to the data, while the ordinary linear expenditure system shows the worst fit. It fits oven more poorly than the "primitive" models". The restrictive assumption of an additive utility function thus does not appear to invalidate the fit of the Iinear expenditure system, but rather the assumption of a constant subsistence level. The linear expenditure system with habit formation also shows the smallest yearly variation in fit. One may also note that the performance of the constant elasticity of demand model is not mich worse than that of the more sophisticated Rotterdam and translog models.

With an eight commodity grouping there are only a few changes in these results. LES still shows the worst fit, but LESH no longer takes a leading position. The translog model now shows a marginally better fit and the unrestricted constant elasticity of denand system fits best of all models. This result is consistent with the preconception that substitution between comodities is more im portant with a finer than with a coarser commodity break-down. Low frequency variation, however, is still important in the expenditure shares series, as shown by the relatively good fit of the simple autoregressive model. The results in these two tables also indicate that the constant elasticity demand system with a suitable number of non-zero cross-price elasticities is still a good altemative to more recent, models.

A comparison of infomation inaccuracies by comodities reveals approximately the same results, although the ranking of the models is not exactly the same for all commodities. For instance, with four commodities the Rotterdan model explains "Basic Supplies" and "Restaurant Meals" relatively well but comes out worse for "Meat and Fish", which is best explained by the linear expenditure system with habit formation and the translog model.

With the eight comodity grouping, CEDS with no restrictions, owing to its many parameters, comes out best for seven commodities. The translog model with a priori fixed error moment matrix comes out best for one commodity and second best for three commodities.

5) For those models which do not satisfy the aggregation constraint, all predicted expenditure shares have been nomalized to sum to unity. The information inaccuracies for the double-log models, the Rotterdam models and the "primitive" models would otherwise have become larger. 
The Rotterdan system with intercepts fits second best for two comodities and the Iinear expenditure system with habit formation second best for one. The ranking is almost the same when judged by the coefficients of detemination, (Tables 5 and 6 ).

on the aggregate level almost all models fail to explain "Vegetables and Fruit", and at the disaggregate level they similarly show a poor fit to the two commodities "Vegetables" and "Fruit, Berries, Ice-crean, Chocolates and Sweets". Residual plots show that the commodity "Vegetables" is systematically overestimated for the first half of the sample period and underestimated for the second. The reverse is true for "Fruit, Berries, Ice-cream, Chocolates, and Sweets". There is no obvious explanation, however.

\subsection{Predictions} - - - - - -

Good fit for the sample period does not necessarily imply good predictions. The last three columns of Tables 1 and 2 show the information inaccuracy arising between observed and predicted expenditure shares for 1971 and 1972. These predictions were made with observed values for prices and total food expenditures per head.

The translog model shows the smallest average infomation inaccuracy followed by the constant elasticity of demand model with no cross-price elasticities. The predictions from the Rotterdam systems as well as those from the naive nodels are relatively poor, while the Inear expenditure system takes ar intemediate position. However, there are large differences in predictive ability for the two years, and this makes a comparison between models difficult. One should perhaps pay relatively more attention to the results for 1971, because this was an exceptional year. For the first time since World War II total private consumption (in constant prices) declined $(-1 \%)$. Total food consumption also declined by 1 per cent. For this year the simple double-log model with no cross-price effects does better than any of the more recent system models. However: the translog model and the linear expenditure system also predict relatively well. 
The same comparison for the eight commodity grouping shows that the autoregressive model has the smallest average information inaccuracy. One is inclined to believe, however, that this good result is exceptional, owing to the very good predictions for 1972. The Rotterdam system (Rd-WDq) and the Iinear expenditure system with habit formation (IESH-po) show the second-best predictions. Except for the trend model, the constant elasticity of demand model with no restrictions and the ordinary linear expenditure system, which all give poor predictions, the differences in predictive ability are small.

If we again pay particular attention to the results for 1971 we find that the two Iinear expenditure systems with habit formation and the constant elasticity of demand model with no crossprice elasticities give the best predictions, closely followed by the translog model (ITRL-W, $\Omega_{0}$ ), the Rotterdam model (RD-W.DQ) and the autoregressive model.

It is also interesting to note, for both levels of aggregation that the many parameters in the constant elasticity of denand model with no restrictions and in the Rotterdam model with intercepts do not guarantee better predictions than those obtained by the corresponding more restrictive models.

\subsection{Comparison of elasticities}

- - - . - - - - - - - -

The estimated elasticities can also be used as a basis for comparison. We may, for instance, investigate if the compensated own-price elasticities are negative for all models and commodities, as is suggested by economic theory. We should also expect expenditure elasticities for luxuary food items to be higher than those for non-luxuries. "Meat and Fish" and "Restaurant Meals" should thus be more expenditure-elastic than "Basic Supplies".

Table 7 shows that only two models give an estimated ownorice elasticity for "Basic Supplies" with the right sign. These are the Iinear expenditure system with habit fomation and the translog model. However, for the Rotterdam and the CEDS models the estimated standard errors are relatively large. 
For the eight comodity grouping, Table 8 exhibits several positive estimates of compensated own-price elasticities. For in stance, the constant elasticity of demand model and the two Rotterdam systems have positive elasticities for "Flour, Bread, Potatoes and derivative products". The Rotterdam systems also give positive elasticities for "Fish" and "Restaurant Meals". With all models except the Rotterdam system with intercepts the estimated price elasticity of "Butter, Egg, Sugar and Spices" is positive. The non-negative estimates for the ordinary linear expenditure system and the Constant Elasticity of Demand System with no crossmprice effects are not due to randon fluctuations, but in most other cases the estimated standard errors are large.

With all models, the estimated income elasticity for Meat and Fish" is higher than the corresponding elasticity for "Basic Supp" lies". The same, however, is not true for "Restaurant Meals". While the Iinear expenditure system gives an estimated income elasticity of 4.2 the translog model suggests that this commodity is inferior. Also, according to the translog model, "Basic Supplies" are incomem elastic, while two other models, the constant elasticity of demand model and the linear expenditure system, indicate that they are inferios:

The results for eight comodities show roughly the sane pattem. In all models, "Vegetables" and "Fruit, Berries, Ice-cream, Chocolates and Sweets" are expenditure-elastic. With few exceptions this is also true for "Meat, Pork and Cheese" and "Fish". The estimates for the linear expenditure systems with habit fomation and the Rotterdam models indicate that "Restaurant Meals" is inelastic while the other models give elasticities well above unity. Almost all models indicate that the three subcomodities within "Basic Supplies" are either inelastic or inferior. The exceptions are the ordinary linear expenditure system ("Flour, Bread, Potatoes and derivative productsin, the constant elasticity of denand model with no restrictions (Milk and Cream") and the translog models (Milk and (cream"). In conclusion, no model confoms exactly with the a priori expected signs and magnitudes of the elasticities.

The comparison of elasticities offered in Tables 7 and 8 also confirms the finding in previous studies that estinates of elasticities crucially depend on the model used. Our eight models give a 
vastly different interpretation of data. With these large differences in estimated elasticities the choice of model may become decisive for forecasting and policy.

\subsection{On the effects of aggregation}

- $-\ldots \ldots-\ldots-\ldots-\ldots$

This study offers a possibility of demonstrating numerically a few effects of comodity aggregation. Aggregation has been analysed for linear models - see, for instance, Theil [1954] and Lutjohann [1974] - but it is an almost unexplored field for non-1inear models. Consistent aggregation is exceptional in linear models, i.e. consistent aggregation requires unrealistically simple micro relations. However, if aggregation is inconsistent there are in general no macro parameters, i.e. the zeudo macro parameters specified depend on the aggregation process and the variables involved. There is no reason to believe that the situation would generally be more favourable for non-linear models.

The estimated elasticities are thus in general not independent of the level of aggregation. The columns for "Restaurant Meals" in Tables 7 and 8 - note that comodities D and 8 are identical - show that in fact they depend on the grouping. With some models - for instance, the ordinary Inear expenditure system and the translog model - the differences in estimated elasticities are large.

There is also an aggregation effect on the goodness of fit as revealed for "Restaurant Meals" by Tables $3-6$. Only for those models which satisfy the budget constraint has a comparison of fit between the two levels of aggregation any meaning. All these models, except the ordinary linear expenditure system, show a closer fit to observed expenditure shares for "Restaurant Meals" when the other commodities are aggregated. There are, however, no large differences in fit.

In order to investigate if predictive performance depends on the level of aggregation the eight predicted expenditure shares have, for each model and year, been aggregated to expenditure shares for the four commodities A - D. Using the sane information inaccuracy measure as before, they are then compared to observed expenditure shares and to those predicted by the aggregate models. Table 9 shows that of the disaggregate models the translog model, the constant elasticity of demand model with no cross-price elasticities and the linear expenditure system with habit fomation give the best 
predictions. This is the sane result as that obtained when the models were estimated on aggregate data (Table 1). For the best models there are no great differences in prediction accuracy due to the level of aggregation, but for some of the inferior models there are. There is however no unique indication that a disaggregate analysis would be superior or vice versa.

\section{Conclusions}

If we would classify our ten models with goodness of fit as the only criterion, two groups might be distinguished. The naive models, the constant elasticity demand model with no cross-price elasticities and the ordinary linear expenditure system would then be classified as inferior and the other models as superior. If the yearly forecasting ability is also taken into consideration the same grouping is obtained, except that the constant elasticity demand system with no cross-price elasticities would now be classiw fied as superior. One conclusion thus is that demand models tend to be superior to naive models. If we also wish to base our cholce on the expected sign and magnitude of estimated elasticities, the Iinear expenditure system with habit fomation and the translog model might be our first preferences, and if, in addition, ease of estimation and applicability are taken into consideration, this study indicates that the linear expenditure system with habit fomation is perhaps our best choice.

With these criteria, and contrary to previous studies (cf. Deaton [ $1974 \mathrm{~b}]$, no severe distortion of measurement is found that is due to the assumption of additivity. The translog model and the Rotterdam system, which are non-additive models, are not found superior to the Iinear expenditure system with habit fomation. Our results, however, also show that there is no obviously best model. Aggregate time series do not give enough infomation to allow a sharp discrimination between models and, in addition, it has been shown that the estimated structures do depend on the level of aggregation. More work is thus needed to analyse the stability of these models, in both the time and the comodity dimensions. This analysis should, inter alia, be based on predictions for a longer period than two years, and include a comparison not only of expenditure shares but also of consumption volume and relative changes in volume. 
Table 1 Average infomation inaccuracies; 4 comodity grouping

\begin{tabular}{|c|c|c|c|c|c|c|}
\hline Model & $\bar{I}_{50-70}$ & $\frac{{ }^{A}}{2_{50-70}}$ & $S_{I, 50-70}$ & $I_{y 1}$ & $I_{72}$ & $\bar{I}_{71-72}$ \\
\hline Trend-W & 325 & 359 & 270 & 751 & 1552 & 1151 \\
\hline Auto-w & 267 & 297 & 5167 & 1.408 & 190 & 799 \\
\hline CEDS-Inq & 245 & 283 & 217 & 128 & 306 & 217 \\
\hline CEDS-InW & 145 & 203 & 134 & 347 & 767 & 557 \\
\hline IESH-pq & 153 & 170 & 128 & 660 & 118 & 389 \\
\hline IESH $-W$ & 145 & 161 & 107 & 713 & 206 & 459 \\
\hline LES-W & 382 & 422 & 440 & 288 & 743 & 525 \\
\hline $\mathrm{RD}-\mathrm{W}^{*} \mathrm{DQ}$ & 190 & 224 & 209 & 1011 & 427 & 719 \\
\hline $\mathrm{RDI}-\mathrm{W}^{*} \mathrm{Dg}$ & 175 & 219 & 189 & 1.170 & 614 & 892 \\
\hline$I I R L-W$ & 211 & 250 & 259 & 336 & 12 & 174 \\
\hline
\end{tabular}

Note: $I_{t}=\sum_{i=1}^{4} w_{i t} \ln \left(w_{i t} / \hat{w}_{i t}\right) \cdot 10^{6}$

$$
\bar{I}=\frac{1}{T} \sum_{t=1}^{T} I_{t}
$$


Table 2 Average information inaccuracies; 8 comodity grouping

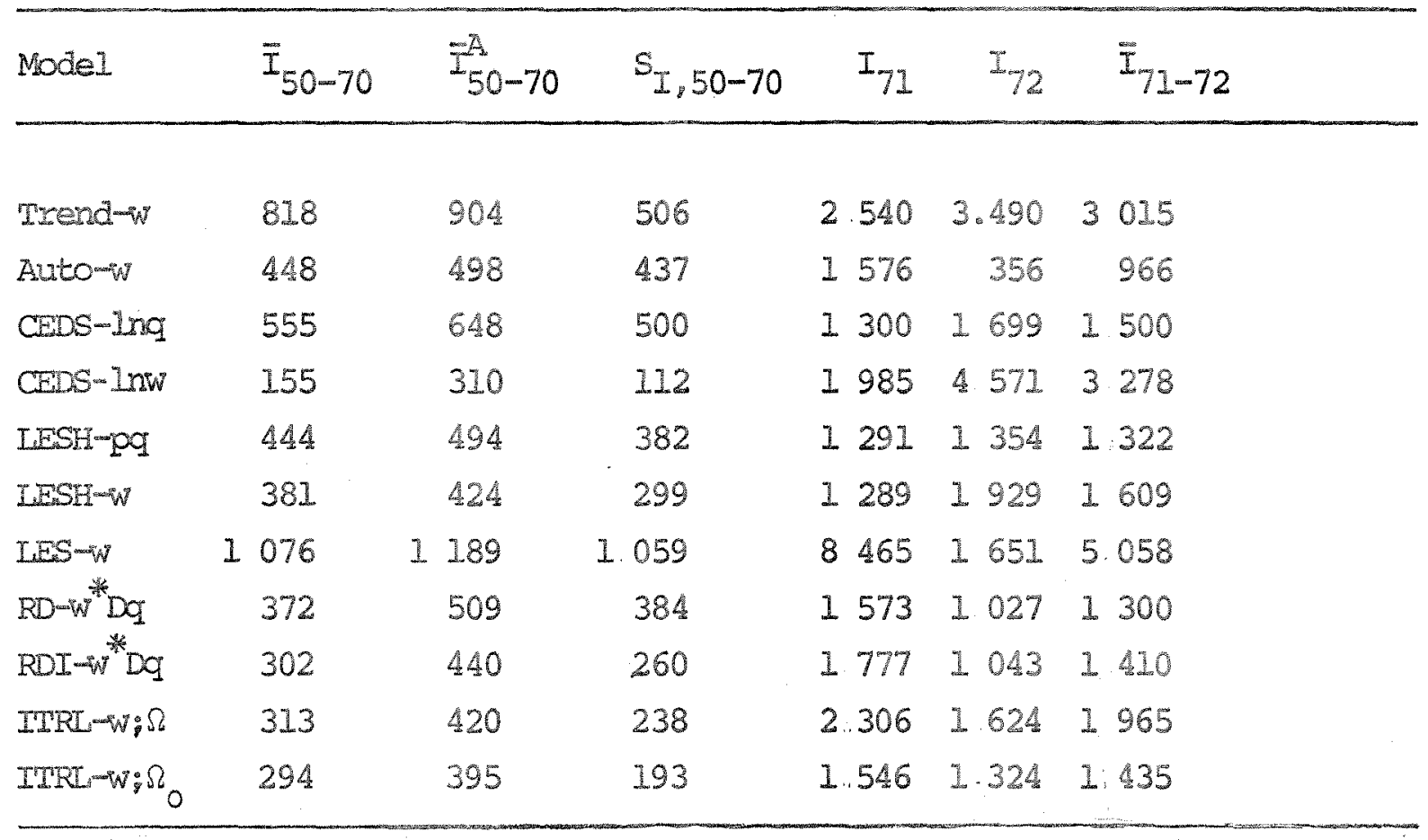


Table 3 Average information inaccuracies by comodity:

4 commodity grouping

\begin{tabular}{|c|c|c|c|c|}
\hline \multirow[t]{2}{*}{ Model } & \multicolumn{4}{|c|}{ Commodity } \\
\hline & $\mathrm{A}$ & B & $\mathrm{C}$ & $D$ \\
\hline Trend-w & 77 & 124 & 58 & $156^{*}$ \\
\hline Autow & 94 & 140 & 50 & $52^{*}$ \\
\hline CaDS Inq & 72 & 113 & 42 & $91^{*}$ \\
\hline CEDS-Inw & $\cdot 23$ & 84 & 23 & 65 \\
\hline IFSH-pq & 52 & 67 & 28 & 53 \\
\hline LESH-W & 46 & 64 & 27 & 51 \\
\hline LES $-W$ & 166 & 142 & 28 & 167 \\
\hline$R D-w^{*} D q$ & 24 & 122 & 47 & 44 \\
\hline $\mathrm{RDI}-\mathrm{W}^{*} \mathrm{DQ}$ & 21 & 114 & 45 & 41 \\
\hline IIRLI-W & 63 & 134 & 27 & 50 \\
\hline
\end{tabular}

* See note to Table 4. 
Table 4 Average infomation inaccuracies by comodity;

8 commodity grouping

\begin{tabular}{|c|c|c|c|c|c|c|c|c|}
\hline \multirow[t]{2}{*}{ Model } & \multicolumn{8}{|c|}{ Comodity } \\
\hline & 1 & 2 & 3 & 4 & 5 & 6 & 7 & 8 \\
\hline Trendwow & 46 & 169 & 168 & 140 & 151 & 58 & 31. & $161^{*}$ \\
\hline Auto-w & 49 & 77 & 50 & 67 & 130 & 62 & 29 & $53^{*}$ \\
\hline CEDS-Ing & 49 & 67 & 80 & 89 & 127 & 45 & 50 & $122^{*}$ \\
\hline CEDS-InW & 19 & 10 & 8 & 28 & 65 & 8 & 9 & 27 \\
\hline IFSH-pq & 20 & 51 & 18 & 162 & 129 & 23 & 22 & 71 \\
\hline IESH-W & 21 & 46 & 15 & 109 & 140 & 22 & 20 & 57 \\
\hline IES-W & 131 & 98 & 316 & 73 & 369 & 34 & 40 & 162 \\
\hline $\mathrm{RD}=\mathrm{w}^{*} \mathrm{*} \mathrm{Dq}$ & 31 & 14 & 25 & 64 & 151 & $5 I$ & 32 & 57 \\
\hline RDI $=w^{*} \mathrm{Dq}$ & 29 & 13 & 15 & 56 & 127 & 41 & 17 & 47 \\
\hline$I T R L-w, \Omega$ & 22 & 30 & 11 & 73 & 113 & 36 & 23 & 48 \\
\hline $\operatorname{IIR}-w_{,}, \Omega_{0}$ & 17 & $5 I$ & 91 & 52 & 18 & 36 & 16 & 53 \\
\hline
\end{tabular}

* The inaccuracy measures for Restaurant Meals and the first three models are not the same for both levels of aggregation, because the expenditure shares have not beer standardized by the same factor. 
Table 5 Coefficients of detemination by comodity

4 commodity grouping

\begin{tabular}{|c|c|c|c|c|}
\hline \multirow[t]{2}{*}{ Model } & \multicolumn{4}{|c|}{ Commodity } \\
\hline & $\mathrm{A}$ & B & $C$ & $D$ \\
\hline Trend-W & 0.9398 & 0.3800 & 0.8328 & 0.6664 \\
\hline Auto-w & 0.9202 & 0.3321 & 0.8500 & 0.8518 \\
\hline CEDS-Ing & 0.9439 & 0.4319 & 0.8803 & 0.8070 \\
\hline CEDS-InW & 0.9992 & 0.5739 & 0.9433 & 0.8703 \\
\hline ILESH-pq & 0.9594 & 0.6650 & 0.9179 & 0.8869 \\
\hline I.ESH-W & 0.9638 & 0.6756 & 0.9215 & 0.8882 \\
\hline IES-W & 0.8714 & 0.2903 & 0.9184 & 0.6527 \\
\hline$R D-w^{*} D q$ & 0.9810 & 0.4050 & 0.8663 & 0.9064 \\
\hline $\mathrm{RDI}-\mathrm{w}^{*} \mathrm{Dq}$ & 0.9832 & 0.4382 & 0.8733 & 0.9121 \\
\hline TIRI-W & 0.9513 & 0.3269 & 0.9213 & 0.8954 \\
\hline
\end{tabular}

$R_{i}^{2}=1-\sum_{t=1}^{T}\left(w_{i t}-\hat{w}_{1 t}\right)^{2} / \sum_{t=1}^{T}\left(w_{1 t}-\hat{w}_{i t}\right)^{2} ; \quad 1=A_{0} \ldots D_{0}$ 
Table 6 coefficlents of detemiration by comodity:

comodity grouping

\begin{tabular}{|c|c|c|c|c|c|c|c|c|}
\hline \multirow[t]{2}{*}{ Model } & \multicolumn{8}{|c|}{ Comodity } \\
\hline & 1 & 2 & 3 & 4 & 5 & 6 & 7 & 8 \\
\hline Trend-W & 0.924 & 0.966 & 0.383 & 0.551 & 0.023 & 0.783 & 0.589 & 0.656 \\
\hline Auto- & 0.913 & 0.980 & 0.796 & 0.765 & 0.114 & 0.765 & 0.594 & 0.850 \\
\hline CEDS-Ing & 0.922 & 0.984 & 0.702 & 0.716 & 0.183 & 0.833 & 0.349 & 0.742 \\
\hline CEDS-Intwil & 0.971 & 0.997 & 0.975 & 0.904 & 0.548 & 0.966 & 0.876 & 0.946 \\
\hline IESH-PQ & 0.965 & 0.988 & 0.926 & .0 .410 & 0.129 & 0.913 & 0.691 & 0.793 \\
\hline LESH-W & 0.963 & 0.989 & 0.938 & 0.594 & 0.025 & 0.915 & 0.727 & 0.829 \\
\hline $\operatorname{IES}-w$ & 0.790 & 0.976 & -0.145 & 0.760 & -1.425 & 0.874 & 0.486 & 0.668 \\
\hline $\mathrm{RD}-\mathrm{w}^{*} \mathrm{Dq}$ & 0.946 & 0.997 & 0.893 & 0.774 & -0.019 & 0.811 & 0.556 & 0.833 \\
\hline RDI w W $D Q$ & 0.948 & 0.997 & 0.936 & 0.802 & 0.143 & 0.847 & 0.765 & 0.861 \\
\hline $\operatorname{ITRL}-\infty, \Omega$ & 0.964 & 0.993 & 0.961 & 0.765 & 0.274 & 0.866 & 0.696 & 0.895 \\
\hline $\operatorname{IIRL}-w_{0}, \Omega_{0}$ & 0.971 & 0.838 & 0.417 & 0.989 & 0.934 & 0.867 & 0.785 & 0.887 \\
\hline
\end{tabular}

1) Predictions of expenditure shares do not sw to 1 . 
Table 7 Income and price elasticities (1960); 4 comodity grouping

\begin{tabular}{|c|c|c|c|c|c|c|c|c|}
\hline \multirow[t]{2}{*}{ Model } & \multicolumn{4}{|c|}{$\begin{array}{l}\text { Income elasticities } \\
\text { cormodity }\end{array}$} & \multicolumn{4}{|c|}{$\begin{array}{l}\text { Compensated own-price elasticlties } \\
\text { comodity }\end{array}$} \\
\hline & $A$ & B & $c$ & $\mathrm{D}$ & A & $B$ & $\mathrm{C}^{\prime}$ & $D$ \\
\hline CEDS-Ing & $\begin{array}{c}-0.787 \\
(0.154)\end{array}$ & $\begin{array}{c}2.115 \\
(0.473)\end{array}$ & $\begin{array}{c}1.273 \\
(0.143)\end{array}$ & $\begin{array}{c}2.348 \\
(0.585)\end{array}$ & $\begin{array}{c}0.823 \\
(0.516)\end{array}$ & $\begin{array}{c}-0.573 \\
(0.225)\end{array}$ & $\begin{array}{c}0.008 \\
(0.044)\end{array}$ & $\begin{array}{c}-0.492 \\
(0.079)\end{array}$ \\
\hline CGUS-Inv & $\begin{array}{c}0.175 \\
(0.148)\end{array}$ & $\begin{array}{c}2.094 \\
(0.523)\end{array}$ & $\begin{array}{c}0.847 \\
(0.202)\end{array}$ & $\begin{array}{c}2.034 \\
(0.527)\end{array}$ & $\begin{array}{c}0.542 \\
(0.258)\end{array}$ & $\begin{array}{c}-0.220 \\
(0.312)\end{array}$ & $\begin{array}{l}-0.338 \\
(0.128)\end{array}$ & $\begin{array}{c}-0.528 \\
(0.217)\end{array}$ \\
\hline IESH - pq & $\begin{array}{c}0.211 \\
(0.082)\end{array}$ & $\begin{array}{l}2.355 \\
(0.270)\end{array}$ & $\begin{array}{l}1.513 \\
(0.164)\end{array}$ & $\begin{array}{l}0.418 \\
(0.308)\end{array}$ & $\begin{array}{c}-0.031 \\
(0.016)\end{array}$ & $\begin{array}{c}-0.341 \\
(0.087)\end{array}$ & $\begin{array}{c}-0.206 \\
(0.053)\end{array}$ & $\begin{array}{c}-0.062 \\
(0.072)\end{array}$ \\
\hline IESH-W & $\begin{array}{c}0.242 \\
(0.055)\end{array}$ & $\begin{array}{c}2.536 \\
(0.211)\end{array}$ & $\begin{array}{c}1.625 \\
(0.147)\end{array}$ & $\begin{array}{c}0.114 \\
(0.260)\end{array}$ & $\begin{array}{c}-0.028 \\
(0.018)\end{array}$ & $\begin{array}{c}-0.493 \\
(0.070)\end{array}$ & $\begin{array}{l}-0.895 \\
(0.043)\end{array}$ & $\begin{array}{c}-0.018 \\
(0.090)\end{array}$ \\
\hline LESW & $\begin{array}{l}-0.662 \\
(0.141)\end{array}$ & $\begin{array}{c}2.224 \\
(0.245)\end{array}$ & $\begin{array}{l}1.196 \\
(0.131)\end{array}$ & $\begin{array}{c}4.223 \\
(0.429)\end{array}$ & $\begin{array}{c}0.263 \\
(0.057)\end{array}$ & $\begin{array}{l}-0.483 \\
(0.043)\end{array}$ & $\begin{array}{c}-0.242 \\
(0.039)\end{array}$ & $\begin{array}{c}-0.633 \\
(0.053)\end{array}$ \\
\hline$R D+w^{*} \mathrm{Dq}$ & $\begin{array}{c}0.400 \\
(0.243)\end{array}$ & $\begin{array}{c}2.320 \\
(0.537)\end{array}$ & $\begin{array}{l}1.181 \\
(0.242)\end{array}$ & $\begin{array}{c}0.648 \\
(0.420)\end{array}$ & $\begin{array}{c}0.199 \\
(0.110)\end{array}$ & $\begin{array}{l}-0.344 \\
(0.222)\end{array}$ & $\begin{array}{c}-0.173 \\
(0.113)\end{array}$ & $\begin{array}{l}-0.083 \\
(0.206)\end{array}$ \\
\hline RDI $-w^{*} \cdot D q$ & $\begin{array}{l}0.422 \\
(0.140)\end{array}$ & $\begin{array}{l}2.417 \\
(0.542)\end{array}$ & $\begin{array}{l}1.56 \\
(0.244)\end{array}$ & $\begin{array}{l}0.530 \\
(0.428)\end{array}$ & $\begin{array}{c}0.100 \\
(0.122)\end{array}$ & $\begin{array}{l}0.390 \\
10.2901\end{array}$ & $\begin{array}{l}-0.231 \\
(0.224)\end{array}$ & -0.142 \\
\hline ITRL $-w$ & 1.251 & 0.917 & 1.238 & $=0.033$ & -1.051 & -0.828 & -1.043 & -1.225 \\
\hline
\end{tabular}

Note: Elasticities for the dymamic models IESH-pq and LESH-w are one-period elasticities.

(Assymototic) standard exrors - in parenthesis - are estinated conditional upon observed expenditure shares and volumes. They are not available for the model IrRT-w. 
Table 8 Incone elasticities using a 8 comodity gromping (1960)

\begin{tabular}{|c|c|c|c|c|c|c|c|c|}
\hline \multirow{2}{*}{ Model } & \multicolumn{7}{|c|}{ comodity } & \multirow[b]{2}{*}{8} \\
\hline & 1 & 2 & 3 & 4 & 5 & 6 & 7 & \\
\hline $\operatorname{cess}-13 q$ & $\begin{array}{c}0.039 \\
(0.421)\end{array}$ & $\begin{array}{c}-1.062 \\
(0.001)\end{array}$ & $\begin{array}{c}1.018 \\
(0.317)\end{array}$ & $\begin{array}{c}4.356 \\
(0.660)\end{array}$ & $\begin{array}{c}1.368 \\
(0.661)\end{array}$ & $\begin{array}{c}1.289 \\
(0.252)\end{array}$ & $\begin{array}{l}1.697 \\
(0.280)\end{array}$ & $\begin{array}{l}-2.350 \\
(0.584)\end{array}$ \\
\hline CDDS-Inw & $\begin{array}{c}0.274 \\
(0.377)\end{array}$ & $\begin{array}{c}-0.268 \\
(0.343)\end{array}$ & $\begin{array}{c}1.242 \\
(0.336)\end{array}$ & $\begin{array}{c}1.514 \\
(1.034)\end{array}$ & $\begin{array}{c}1.806 \\
(0.854)\end{array}$ & $\begin{array}{c}0.521 \\
(0.212)\end{array}$ & $\begin{array}{l}1.442 \\
(0.549)\end{array}$ & $\begin{array}{l}1.700 \\
(0.505)\end{array}$ \\
\hline LFSH & $\begin{array}{l}0.629 \\
(0.104)\end{array}$ & $\begin{array}{r}0.027 \\
(0.027)\end{array}$ & $\begin{array}{c}0.447 \\
(0.027)\end{array}$ & $\begin{array}{c}2.178 \\
(0.205)\end{array}$ & $\begin{array}{c}1.931 \\
(0.293)\end{array}$ & $\begin{array}{c}1.491 \\
(0.119)\end{array}$ & $\begin{array}{l}0.807 \\
(0.211\rangle\end{array}$ & $\begin{array}{l}0.714 \\
(0.089)\end{array}$ \\
\hline IRSE -W & $\begin{array}{l}0.463 \\
(0.099)\end{array}$ & $\begin{array}{l}-0.001 \\
(0.037)\end{array}$ & $\begin{array}{l}0.461 \\
(0.036)\end{array}$ & $\frac{1.471}{(0.262)}$ & $\begin{array}{c}2.410 \\
(0.176)\end{array}$ & $\begin{array}{l}1.561 \\
(0.230)\end{array}$ & $\begin{array}{l}1.066 \\
10.216)\end{array}$ & $\begin{array}{c}0.389 \\
(0.114)\end{array}$ \\
\hline LESWW & $\begin{array}{l}1.133 \\
(0.126)\end{array}$ & $\begin{array}{l}-1.148 \\
(0.144)\end{array}$ & $\begin{array}{l}-0.568 \\
(0.123)\end{array}$ & $\begin{array}{c}4.633 \\
(0.364)\end{array}$ & $\begin{array}{c}2.165 \\
(0.188)\end{array}$ & $\begin{array}{l}1.298 \\
(0.091)\end{array}$ & $\begin{array}{c}1.541 \\
(0.199)\end{array}$ & $\begin{array}{c}1.380 \\
(0.096)\end{array}$ \\
\hline $\mathrm{RD}-\mathrm{W}^{*} \mathrm{DQ}$ & $\begin{array}{c}0.397 \\
(0.356)\end{array}$ & $\begin{array}{l}0.607 \\
(0.236)\end{array}$ & $\begin{array}{c}0.653 \\
(0.435)\end{array}$ & $\begin{array}{c}1.603 \\
(1.221)\end{array}$ & $\begin{array}{c}2.496 \\
(0.833)\end{array}$ & $\begin{array}{l}1.233 \\
(0.352)\end{array}$ & $\begin{array}{c}1.209 \\
(0.721)\end{array}$ & .0 .444 \\
\hline RUI -w* Dq & $\begin{array}{c}0.211 \\
(0.368)\end{array}$ & $\begin{array}{c}0.634 \\
0.286)\end{array}$ & $\begin{array}{c}0.647 \\
(0.366)\end{array}$ & $\begin{array}{c}1.603 \\
(1.210)\end{array}$ & $\begin{array}{c}2.396 \\
(0.825)\end{array}$ & $\frac{1.246}{(0.335)}$ & $\frac{2.201}{(0.574)}$ & 0.455 \\
\hline $\operatorname{IrNL}-w_{\Omega} \Omega$ & 0.047 & 0.191 & 1.565 & 3.697 & 1.401 & 0.933 & 2.686 & 1.377 \\
\hline IMRL $-N_{0}, \Omega_{0}$ & 0.323 & 3.431 & 1.245 & 0.307 & 1.358 & 0.853 & 1.035 & 1.706 \\
\hline
\end{tabular}

Compensated own-parice elasticities (1960)

\begin{tabular}{|c|c|c|c|c|c|c|c|c|}
\hline \multirow{2}{*}{ Model. } & \multicolumn{8}{|c|}{ Commodity } \\
\hline & 1 & 2 & $3^{?}$ & 4 & 5 & 6 & 2 & 8 \\
\hline CEOS Ino & $\begin{array}{c}0.342 \\
(0.114)\end{array}$ & $\begin{array}{l}0.460 \\
(0.141)\end{array}$ & $\begin{array}{c}-0.559 \\
(0.107)\end{array}$ & $\begin{array}{c}-1.046 \\
(0.145)\end{array}$ & $\begin{array}{l}-0.981 \\
(0.216)\end{array}$ & $\begin{array}{c}-0.463 \\
(0.064)\end{array}$ & $\begin{array}{l}-0.087 \\
(0.233)\end{array}$ & $\begin{array}{l}-0.781 \\
10.079)\end{array}$ \\
\hline CEDS-InW & $\begin{array}{l}-0.214 \\
(0.126)\end{array}$ & $\begin{array}{c}0.466 \\
(0.255)\end{array}$ & $\begin{array}{c}-0.202 \\
(0.157)\end{array}$ & $\begin{array}{c}-0.586 \\
(0.376)\end{array}$ & $\begin{array}{l}0.134 \\
(0.586)\end{array}$ & $\begin{array}{l}-0.830 \\
(0.123)\end{array}$ & $\begin{array}{c}0.020 \\
(0.514)\end{array}$ & $\begin{array}{c}-0.703 \\
(0.429)\end{array}$ \\
\hline LESS-PQ & $\begin{array}{l}-0.298 \\
(0.030)\end{array}$ & $\begin{array}{c}0.013 \\
(0.012)\end{array}$ & $\begin{array}{c}-0.163 \\
(0.007)\end{array}$ & $\begin{array}{c}-0.661 \\
(0.075)\end{array}$ & $\begin{array}{l}-0.562 \\
(0.064)\end{array}$ & $\begin{array}{l}-0.359 \\
(0.027)\end{array}$ & $\begin{array}{l}-0.283 \\
(0.081)\end{array}$ & $\begin{array}{c}-0.216 \\
(0.035)\end{array}$ \\
\hline IESR:-N & $\begin{array}{c}-0.257 \\
(0.037)\end{array}$ & $\begin{array}{c}0.029 \\
(0.015)\end{array}$ & $\begin{array}{l}-0.176 \\
(0.013)\end{array}$ & $\begin{array}{l}-0.503 \\
(0.069)\end{array}$ & $\begin{array}{l}-0.670 \\
10.0551\end{array}$ & $\begin{array}{l}-0.390 \\
(0.033)\end{array}$ & $\begin{array}{l}-0.404 \\
(0.084)\end{array}$ & $\begin{array}{c}-0.127 \\
(0.046)\end{array}$ \\
\hline Itos & $\begin{array}{c}-0.314 \\
(0.022)\end{array}$ & $\begin{array}{c}0.308 \\
(0.019)\end{array}$ & $\begin{array}{l}0.147 \\
(0.012)\end{array}$ & $\begin{array}{c}-1.134 \\
(0.013)\end{array}$ & $\begin{array}{l}-0.583 \\
(0.026)\end{array}$ & $\begin{array}{l}-0.353 \\
(0.022)\end{array}$ & $\begin{array}{l}-0.382 \\
(0.020)\end{array}$ & $\begin{array}{l}-0.366 \\
(0.012)\end{array}$ \\
\hline $\mathrm{BD}=\mathrm{N}^{*} \mathrm{DQ}$ & $\begin{array}{l}0.054 \\
10.1451\end{array}$ & $\begin{array}{c}0.196 \\
(0.127)\end{array}$ & $\begin{array}{l}-0.097 \\
(0.138)\end{array}$ & $\begin{array}{l}-0.556 \\
(0.263)\end{array}$ & $\begin{array}{l}-0.526 \\
(0.276)\end{array}$ & $\begin{array}{c}-0.302 \\
(0.131)\end{array}$ & $\begin{array}{c}0.372 \\
(0.3541\end{array}$ & 0.223 \\
\hline $\mathrm{ROH}^{*}{ }^{*} \mathrm{Dq}$ & $\begin{array}{l}0.013 \\
(0.156)\end{array}$ & $\begin{array}{c}-0.187 \\
(0.135)\end{array}$ & $\begin{array}{l}-0.147 \\
(0.145)\end{array}$ & $\begin{array}{c}-0.636 \\
(0.274)\end{array}$ & $\begin{array}{c}-0.374 \\
(0.446)\end{array}$ & $\begin{array}{r}-0.328 \\
(0.131)\end{array}$ & $\begin{array}{l}0.59 \\
(0.326)\end{array}$ & 0.311 \\
\hline$I T R-w, \Omega$ & 0.369 & 0.486 & -0.089 & -0.807 & -0.674 & -0.343 & 0.004 & -0.097 \\
\hline $\operatorname{THRL}-W_{3} \Omega_{0}$ & -0.138 & -0.628 & -0.334 & -0.823 & -0.033 & -0.329 & -0.129 & -0.250 \\
\hline
\end{tabular}

Note: Elasticities for the dyramic models LESE-pq and IFSE-W are one-period elasticities.

(Assymptotic) standard errors - in parenthesis - are estimated conditional upon observed axcenditure shares and volumes. They are not available for the model IITRLwiv. 
Table 9 Infomation inaccuracies for predictions obtained by aggregation from 8 to 4 comodities

\begin{tabular}{|c|c|c|c|}
\hline Model & $u_{y 1}$ & $I_{72}$ & $\bar{I}_{71-72}$ \\
\hline Trend-w & 735 & 1535 & 1135 \\
\hline Auto-w & 1.008 & 189 & 599 \\
\hline CEDS-Ing & 105 & 366 & 235 \\
\hline CEDS-Inw & 611 & 2784 & 1697 \\
\hline IESH-pq & 493 & - 285 & 389 \\
\hline LESH-W & 553 & 236 & 395 \\
\hline IES- $w$ & 3038 & 257 & 1645 \\
\hline $\mathrm{RD}-w^{*} \mathrm{Dq}$ & 1099 & 614 & 856 \\
\hline$R D I-w^{*} D q$ & 7045 & 880 & 3963 \\
\hline ITRL-W, 0 & 103 & 109 & 106 \\
\hline $\operatorname{ITRL}-w_{2} \Omega_{0}$ & 321 & 201 & 161 \\
\hline
\end{tabular}


6. References

Barten, A.P., 1969, Maximum Likelihood Estimation of a Complete System of Demand Equations; European Economic Review. 1, 7-73

Bradley, E.L., 1973, The equivalence of Maximum Likelihood and Weighted Least Squares Estimates in the Exponential Family, Joumal of American Statistical Society $68,199-200$

Brown, A. \& Deaton, A., 1972, Surveys in Applied Economics: Models of Consumer Behaviour. The Economic Joumal $82,1145-1236$

Byron, R.P., 1970, The restricted Aitken estimation of sets of denand relations, Econometrica 38, 816-830

Chames, A., Frome, E.L. and Yu, P.L., 1976, the Equivalence of Generalized Least Squares and Maximm Likelihood Estimates in the Exponential Family, Joumal of the American Statistical Association 71, 169-171

Christensen, L.R., Jorgenson, "D.W. \& Lau, L.J., 1975, Transcendental Logarithmic Utility Functions, The American Bconomic Review, Vol. LXV, No, 3

Christensen, L.R. and Manser, M.E., 1977, Estimating U.S. Consumer preferences for meat with a flexible utility function, Journal of Econometrics 5, $37-54$

Dahlman, C.J. \& Klevmarken, A., 1971, Den privata konsuntionen 1931-1975. Industriens Utredningsinstitut. (Almqvist \& Wikse11 Intemational, Stockholm)

Deaton. A.S., 1974 a, The Analysis of Consumer Demand in the United Kingdom 1900-1970, Econometrica 42, 341-368

Deaton, A.S., 1974 b, A reconsideration of the empirical implications of additive preferences, Economic Joumal 84; (June 1974)

Deaton, A.S., 1975, Models and Projections of Demand in Postwhar Britain, (Chapman and Hall, London)

Gamaletsos, Th., 1973, Further Analysis of Cross-Country Comparison of Consumer Expenditure Pattems, European Economic Review 4, $1-20$

Goldberger, A.S. and Gamaletsos, T., A cross-country comparison of expenditure pattems, European Economic Review (Spring 1970) $357-400$

Houthakker, H.S., 1960, Additive preferences, Bconometrica 28, $244-257$

Lutjoham, H. 1974, Linear Aggregation in Linear Regression, (Sundt Offset, Stockholm) 
Oberhofer, W. and Knenta, J., 1974, A General Procedure for Obtaining Maximum Likelihood Estimates in Generalized Regression Models, Econometrica 42,579-590

Parks, R.W. 1969, Systems of Demand Equations: an empirical comparison of alternative functional forms. Econometrica 37. $629-650$

Pollak, R.A., 1970, Habit fomation and dynamic demand functions, Joumal of Political Economy $78,745-763$

Pollak, R.A. and Wales, T.J., 1969, Estimation of the linear expenditure system, Econometrica 37, 611-628

Schultz, H., 1938, The Theory and measurement of demand (Chicago University Press).

Stone, J.R.N., 1954, Linear expenditure systems and demand analysis: an application to the pattem of British Denand, Economic Jouma1 64, 511-527

Theil, H., 1954, Linear Aggregation in Economic Relations, (NorthHolland, Ansterdan)

Theil, H., 1971, principles of Econometrics, North-Holland, Amsterdam)

Thei1, H., 1975, Theory and Measurement of Consumer Demand, Vo1. 1, (North-Holland/American Elsevier, Amsterdam)

Wold, H., 1952, Demand analysis, (Almqvist and Wikse11, Uppsala)

Yoshihara, K., 1969, Demand Functions: An Application to the Japanese expenditure pattem, Econometrica 37, 257-274 